another on the political and social impact of cars on the Motherland.

As such, the book focuses on the main auto producing cities (the vast "Soviet Detroits"), Russia's age-old problems of poor roads, the use and meaning of autos in the Soviet era, and how the increase in car usage came to be seen as a political and ideological problem for the government. Along the way, Siegelbaum inundates the reader with fascinating tales of Soviet Russia's auto revolution - from the pervasive influence of foreign manufacturers (Fords and Fiats were long part of the Soviet autoscape, the latter built in Togliatti, a massive car city named after the Italian Communist leader), to the role played by cars in the October Revolution (Kerensky attempted to flee in one, but the Bolsheviks had disabled all of them the previous night), to images of Lenoid Breshnev's driver's license. A true voyage of discovery for Siegelbaum, and clearly a labour of love, at times the book reads like a personal travel memoir.

Fighting Traffic and Cars for Comrades are two very different books, yet for all the geographic and disciplinary distance between them, they are intimately connected: Siegelbaum's book shows how the growing desire (not the more state-controllable demand, as Siegelbaum makes clear) for cars and the private personal mobility they represented was incongruent with the dictates of communism; Norton's book illustrates how the growth of personal mobility in the US was incongruent with the idea of public space. In each case, motordom won out over the notion of the commonweal, in both instances with very mixed results. Ultimately, the car might have meant freedom, but as both books demonstrate, the cost was tremendous - be it the right to walk across the street, or the very notion of collective effort. The ubiquitous car plays a role in shaping cities, and toppling empires, too.

Dimitry Anastakis

Trent University

\title{
Luis Alvarez, The Power of the Zoot: Youth Culture and Resistance During World War II (Berkeley: University of California Press, 2008).
}

With this fascinating work of scholarship Luis Alvarez bridges social and cultural history, Chicano and African American History, Ethnic Studies and American Studies. The book's comparative structure linking Los Angeles and New York City both broadens and deepens its analysis of youth culture, style politics, citizenship, race, gender, sexuality, and class. The author successfully sheds new light on a multifaceted subject, arguing that hep cats, pachucos, and pachucas "employed a 'body politics of dignity" (9) as a way to resist being segregated, regulated, racialized, criminalized, and dehumanized. He situates popular culture as a site of everyday politics, and the body as a site of power relations, all within the context of the Double $\mathrm{V}$ campaign to defeat fascism abroad and dis- 
crimination at home. In his introduction and throughout chapters on political economy, class politics, body politics, jazz and public space, and vigilante race riot violence, Alvarez develops his theses that young male and female zoot suiters played a critical role as subversive others in the national debate over identity and belonging in American culture, and that they "practiced a complicated and sometimes contradictory cultural politics in which they did not simply assimilate into wartime society or rebel against it" (10). By the end of an epilogue that connects the zoot era to present-day youth culture, the study ultimately persuaded me of both the power of the title, and the resistance of the subtitle.

Methodologically, the author draws from key secondary sources in new ways, from primary documents, including many personal papers, special collections, and oral histories, as well as twenty contemporaneous illustrations, and from seven original author interviews of former zoot suiters to fill in gaps in the historiography. Within American History, Alvarez pushes the periodization of the civil rights movement farther back to the war years, and he weaves Chicanos into the American tapestry of GI's, sailors, and Rosie the Riveters. Within Chicano History, he revisits World War II as a turning point for Mexican Americans challenging segregation and pursuing upward mobility, and he foregrounds the complex relationship between the Chicana/o and the African American experiences. Alvarez employs - and validates - cultural studies theories by substantiating his claims with historical evidence based on rigorous research. The Power of the Zoot could thus be taught in undergraduate courses on the 1940s, black-brown relations, or popular culture, as well as in graduate seminars on cultural politics, historiography, or American Studies. The book speaks to related studies of youth cultures, subcultures, whiteness, and urban space, it adds to constructs such as "imagined community" and "social horizon," and it introduces new concepts such as "subaltern counterpublic" $(116,151)$ and zoot "mobilization" (79-81).

One can still argue over whether the cultural production of the zoot suiters represented a nascent form of radical politics; whether the draped youth, with their politics of the possible, were transforming the system or, with their politics of refusal, not even reforming it. Nevertheless, Alvarez enlivens this long-standing debate over the larger significance of the zoot suit by grounding his cultural analysis in socioeconomic factors, and by acknowledging the existence of both "opposition and accommodation" (9), as well as the limitations such as consumerism and sexism - of the somewhat indirect zoot challenge to America's "structures of domination" (244). After methodically illustrating how the mainstream press demonized nonwhite youth as dirty, foreign, deviant, immoral, and violent, and how conservative and liberal whites "framed the p roblem of juvenile delinquency in racial terms" (51), he convincingly demonstrates how "zoot suiters claimed dignity by asserting their public presence" (115).

In the end, the author places racial minorities on the center stage of a 
wartime morality play, not as an ideological move, or even a revisionist recovery, but because the brown bodies in question were in fact engaged in a dramatic struggle for dignity on the home front, one that called into question the dominant discourses of American democracy, liberty, and equality. By consistently comparing the East and West Coasts, by using examples from Texas, and by analyzing the so-called zoot suit riots of Los Angeles and Harlem along with those of Detroit and of the South, Alvarez inserts Mexican Americans and African Americans into the all-too-often nostalgic national narrative of the Depression-World War II "Greatest Generation." The book therefore has the topical appeal and intellectual import to attract non-specialist academic readers, as well as those from a broader general audience interested in "interethnic cultural exchange," "social relationships that value rather than denigrate difference," and the power of "social spaces and cultural identities" (243).

Anthony Macías

University of California, Riverside

\section{David H. Price, Anthropological Intelligence: The Deployment and Neglect of American Antbropology in the Second World War (Durham: Duke University Press, 2008).}

Contemporary anthropology shares some general awareness about the field's professional contributions to the Second World War on the US side, but the actual range of US anthropologists' engagement so far was not well understood. Most among anthropology's active participants refrained from publishing about it in any detail after 1945. For the next generations of scholars, anthropology's involvement in a just war against Nazism and fascism seemed to raise few questions, and thus merely attracted mild scholarly interest.

It took the new international contexts of the late Cold War era and of the present post-Cold War times, to bring that difference between general awareness and lack of actual knowledge and understanding back to scholars' attention. Recent military challenges for contemporary anthropology, such as the US presence in Iraq since 2003 and the debate about scholars' involvement in it, further contributed toward transforming that difference between awareness and knowledge into a new and timely research field: How did it all begin? What were the historical foundations of US anthropology's involvement with the military, and which directions did it take?

David Price pursued these questions at first as one element within an important earlier project of his. When he researched the archives for his "Threatening Anthropology" volume (2004) about the FBI's surveillance of activist anthropologists in the McCarthy era, he discovered that many scholars' cooperation with intelligence and military services originated in the years before 